\title{
PERANCANGAN SISTEM PENCARIAN NAMA LATIN TUMBUHAN BERBASIS WEBSITE MENGGUNAKAN ALGORITMA KNUTH MORRIS PRATT
}

\author{
Anofrizen \\ Jurusan Sistem Informasi, Fakultas Sains dan Teknologi, UIN Sultan Syarif Kasim Riau \\ Jl. HR. Soebrantas No. 155 Simpang Baru, Panam, Pekanbaru, 28293 \\ Email: anofrizen@uin-suska.ac.id
}

\begin{abstract}
ABSTRAK
Biologi merupakan salah satu pelajaran yang memiliki banyak istilah. Berdasarkan struktur keilmuan menurut Biological Science Curriculum Study (BSCS), istilah dan objek yang berjumlah ribuan jenis menjadi kesulitan tersendiri untuk dipelajari. Salah satu cara mempermudah dalam mempelajarinya adalah pengelompokan atau pengklasifikasian makhluk hidup disebut taksonomi dan tata nama ilmiah yang disebut binomial nomenklatur. Klasifikasi dan tata nama ilmiah masuk dalam mata pelajaran Ilmu Pengetahuan Alam (IPA) tingkat SMP, Biologi tingkat SMA dan Perguruan Tinggi. Pada silabus pembelajaran mata pelajaran IPA pada SMP N 7 Pekanbaru sumber belajar hanya didapat dari buku-buku, tentu ini kurang efektif untuk mepelajari tentang klasifikasi dan tata nama ilmiah tumbuhan bagi pelajar dikarenakan banyaknya jenis dan spesias tumbuhan yang ada. Perancangan sistem pencarian nama latin tumbuhan ini menggunakan metode Object Oriented Analysis and Design (OOAD) karena metode ini menekankan pada sisi objek penggunanya. Dari hasil penelitian ini didapatkan bahwa sistem tersebut dapat membantu user dalam melakukan pencarian nama latin tumbuhan berdasarkan keyword yang telah di inputkan sebelumnya.
\end{abstract}

Kata kunci: Knut Morris Pratt, Nama Latin, Taksonomi, Tumbuhan.

\section{ABSTRACT}

Biology is a subject that has many terms. Based on the scientific structure according to the Biological Science Curriculum Study (BSCS), the terms and objects which number in thousands of species are difficult to learn. One way to make it easier to learn is the classification or classification of living things called taxonomies and scientific nomenclature called binomial nomenclature. Scientific classification and nomenclature are included in Natural Sciences (SMP) at the junior high school level, Biology at the high school level, and at the tertiary level. In the syllabus of science learning subjects at SMP N 7 Pekanbaru learning resources are only obtained from books, of course this is less effective for learning about the scientific classification and nomenclature of plants for students due to the many types and specializations of plants that exist. The design of the plant's Latin name search system uses the Object Oriented Analysis and Design (OOAD) method because this method emphasizes the user side of the object. From the results of this study it was found that the system can help users in searching for Latin names of plants based on keywords that have been inputted before.

Keywords: Knut Morris Pratt, Latin Names, Taxonomies, Plants.

\section{Pendahuluan}

Kehidupan manusia tidak lepas dengan adanya berbagai macam makhluk hidup lainnya yang berada di alam semesta seperti hewan dan tumbuhan dimana itu semua terdapat dan bisa kita pelajari dalam dunia biologi. Biologi merupakan salah satu pelajaran yang memiliki banyak istilah. Berdasarkan struktur keilmuan menurut Biological Science Curriculum Study (BSCS), istilah dan objek yang berjumlah ribuan jenis menjadi kesulitan tersendiri untuk dipelajari. Salah satu cara mempermudah dalam mempelajarinya adalah pengelompokan atau pengklasifikasian makhluk hidup disebut taksonomi dan tata nama ilmiah yang disebut binomial nomenklatur.

Salah satu istilah biologi yang sering digunakan untuk keperluan pendidikan adalah klasifikasi (taksonomi) dan tata nama ilmiah pada tumbuhan (plantae). Ilmu biologi dalam dunia pendidikan di sekolah mulai dari pelajar Sekolah Menengah Pertama (SMP), Sekolah Menengah Atas (SMA), dan mahasiswa mempelajari klasifikasi dan tata nama ilmiah untuk tumbuhan yang menggunakan bahasa latin atau bahasa lain yang dilatinkan. Klasifikasi dan tata nama ilmiah masuk dalam mata pelajaran atau matakuliah Ilmu Pengetahuan Alam (IPA) tingkat SMP, Biologi tingkat SMA dan Perguruan Tinggi. Alat bantu yang 
digunakan pada umumnya dalam memahami klasifikasi dan tata nama ilmiah tumbuhan yang terdiri dari Kingdom, Sub Kingdom, Super Divisi, Divisi, Kelas, Sub Kelas, Ordo, Family, Genus, dan Spesies adalah buku pelajaran atau tabel klasifikasi dan tata nama ilmiah. Dengan banyaknya jenis dan spesies tumbuhan, sehingga menyulitkan siswa dalam melakukan pencarian dan mempelajari klasifikasi dan nama ilmiah tumbuhan yang mengakibatkan terjadinya kesalahan dalam penulisan klasifikasi dan tata nama ilmiah pada tumbuhan.

Pada Sekolah Menengah Pertama Negeri (SMP N) 7 Pekanbaru yang beralamatkan di Jl. Lokomotif No.28, Tj. Rhu, Lima Puluh, Kota Pekanbaru, Riau, pelaksanaan pembelajaran IPA dilaksanakan dengan pedoman kurikulum 2013. Salah satu materi IPA kelas VII ialah memahami keanekaragaman makhluk hidup, yang mana terdapat materi pembelajaran mengenai klasifikasi dan tata nama ilmiah tumbuhan. Pada silabus pembelajaran mata pelajaran IPA pada SMP N 7 Pekanbaru sumber belajar hanya didapat dari bukubuku, tentu ini kurang efektif untuk mepelajari tentang klasifikasi dan tata nama ilmiah tumbuhan bagi pelajar dikarenakan banyaknya jenis dan spesias tumbuhan.

Seiring dengan pesatnya perkembangan teknologi, Asosiasi Penyelenggara Jasa Internet Indonesia (APJII) berdasarkan siaran pers mengemukakan penggunaan internet di Indonesia pada tahun 2016 mencapai 132,7 juta atau setara dengan $51,8 \%$ dari jumlah penduduk Indonesia. Melihat dari penggunaan internet di Indonesia salah satu jenis konten yang paling sering di akses atau dicari ialah konten pendidikan yaitu sebesar 93,8\% atau setara dengan 124,4 juta dengan menggunakan perangkat Smartphone $(67,8 \%)$, Komputer/Pc $(14,7$ $\%)$, Laptop (12,6\%) dan Tablet $(3,8)$ [1].

Pencarian (searching) adalah proses pencarian suatu data dari sekumpulan data yang sudah ada berdasarkan kata kunci yang menghasilkan nilai benar (ketemu atau sukses) atau salah (tidak ketemu atau tidak sukses) [2]. Dalam ilmu komputer terdapat bermacam-macam algoritma untuk metode pencarian maupun pencocokan string. Salah satunya ialah algoritma Knuth Morris Pratt (KMP).

Algoritma Knuth Morris Pratt merupakan salah satu algoritma string matching dikembangkan secara terpisah oleh James $H$. Morris bersama Vaughan R. Pratt pada tahun 1966 dan Donald E. Knuth pada tahun 1967, kemudian dipublikasikan secara bersamaan pada tahun 1977. Algoritma Knuth Morris Pratt atau biasa disingkat algoritma KMP melakukan perbandingan karakter teks dan karakter pattern pada pola dari kiri ke kanan. Ide dari algoritma ini adalah bagaimana memanfaatkan karakter-karakter pattern yang sudah diketahui ada di dalam teks sampai terjadinya ketidak cocokkan untuk melakukan pergeseran [3].

Untuk membantu pelajar khususnya siswa kelas VII SMP N 7 Pekanbaru dalam mempelajari klasifikasi dan tata nama ilmiah pada tumbuhan maka penulis tertarik untuk membuat dan merancang sistem pencarian klasifikasi dan tata nama ilmiah pada tumbuhan berbasis website dengan menggunakan algoritma Knuth Morris Pratt. Perancangan sistem berbasis website ini dimaksudkan agar sistem yang dibuat dapat diakses melalui perangkat apa saja.

Dengan adanya aplikasi ini diharapkan dapat memudahkan pelajar ataupun mahasiswa dalam memahami dan mempelajari klasifikasi dan tata nama ilmiah pada tumbuhan, sehingga tidak akan terjadi lagi kesalahan dalam penulisan klasifikasi dan tata nama ilmiah pada tumbuhan serta dapat digunakan dan diakses dimana saja selagi terhubung dengan internet.

\section{Tinjauan Pustaka}

\section{Bahasa Latin}

Bahasa Latin adalah sebuah bahasa Italik yang berasal dari Latium, sebuah daerah di Italia sekeliling kota Roma yang termasuk dalam rumpun Indo Eropa. Bahasa ini menjadi penting karena munculnya kekaisaran Romawi dimana bahasa Latin adalah bahasa resminya. Pada puncak kejayaan kerajaan ini, bahasa Latin dituturkan dari pulau Britania di barat laut sampai Palestina di ujung tenggara dengan kata lain menjadi bahasa Internasional [4].

Bahasa Latin juga mempunyai turunan yang disebut sebagai sermo vulgaris (bahasa Roman/bahasa Latin Rakyat) yang dituturkan oleh antara lain bala tentara Romawi menjadi pengantar di seluruh daerah kerajaan. Di beberapa tempat bahasa ini bahkan menggantikan bahasa setempat, bahkan bahasa Inggris pun sebagian besar diambil dari bahasa latin ini (selain bahasa Yunani Kuno tentunya) [4].

\section{Tumbuhan}

Tumbuhan adalah organisme benda hidup yang terkandung dalam alam Plantae. Biasanya, organisme yang menjalankan proses fotosintesis adalah diklasifikasikan sebagai tumbuhan. Tumbuhan memerlukan cahaya matahari untuk menjalani proses fotositesis.

Tumbuhan merangkumi semua benda hidup yang mampu menghasilkan makanan dengan menggunakan klorofil untuk menjalani proses fotosintesis dan menghasilkan kanji. Sel tumbuhan berbeda dengan sel hewan, dalam beberapa segi sel tumbuhan mempunyai dinding sel [5]. 


\section{Algoritma Knuth Morris Pratt}

Algoritma Knuth Morris Pratt (KMP) merupakan salah satu algoritma string matching dikembangkan secara terpisah oleh James H. Morris bersama Vaughan R. Pratt pada tahun 1966 dan Donald E. Knuth pada tahun 1967, kemudian dipublikasikan secara bersamaan pada tahun 1977 [6]

Algoritma Knuth Morris Pratt merupakan pengembangan dari algoritma pencarian string sebelumnya, yaitu algoritma Brute Force. Algoritma Brute Force merupakan algoritma dasar yang paling sederhana dalam menyelesaikan persoalan pencocokan string yang melakukan pencarian pada setiap posisi di dalam teks antara 0 dan $n-m$, dimana $n$ adalah panjang teks atau banyaknya nama file yang tersimpan dikomputer dan $m$ adalah panjang karakter dari suatu pattern (kata yang akan dicari) [8].

Secara sistematis, langkah-langkah yang dilakukan algoritma Knuth Morris Pratt pada saat mencocokkan string) [2][9]:

1. Masukkan Query kata yang akan dicari. Dengan permisalan $\mathrm{P}=$ Pattern atau pola susunan kata yang dijadikan sebagai contoh atau pola teks yang akan dicari $\mathrm{T}=$ Teks atau judul dokumen.

2. Algoritma Knuth Morris Pratt mulai mencocokkan pattern atau pola susunan kata yang dijadikan sebagai contoh pada awal teks.

3. Dari kiri ke kanan, algoritma ini akan mencocokkan karakter per karakter pattern atau pola susunan kata yang dijadikan sebagai contoh dengan karakter di teks yang bersesuaian, sampai salah satu kondisi berikut dipenuhi:

a. Karakter di pattern atau pola susunan kata yang dijadikan sebagai contoh dan di teks yang dibandingkan tidak cocok (mismatch).

b. Semua karakter di pattern atau pola susunan kata yang dijadikan sebagai contoh cocok. Kemudian algoritma akan memberitahukan penemuan di posisi ini.

c. Algoritma kemudian menggeser pattern atau pola susunan kata yang dijadikan sebagai contoh berdasarkan tabel next, lalu mengulangi langkah no. 2 sampai pattern atau pola susunan kata yang dijadikan sebagai contoh berada di ujung teks.

\section{Pendekatan Beorientasi Objek}

Pendekatan berorientasi objek merupakan paradigma pemograman yang berorientasikan kepada objek. Semua data dan fungsi di dalam paradigma ini dibungkus dalam kelas-kelas atau objek-objek.

Pada objek oriented terdapat beberapa model pendekatan, yaitu Object Oriented Programming (OOP) dan Object Oriented Analysis and Design (OOAD). OOP atau pemograman berorientasi objek adalah konsep pemograman yang difokuskan pada penciptaan kelas yang merupakan abstraksi/blueprint/prototype dari suatu objek. Kelas ini harus mengandung sifat (data) dan tingkah laku (method) umum yang dimiliki oleh objek-objek yang kelak akan dibuat (diinstansiasi). Data dan method merupakan anggota dari suatu kelas. Sedangkan OOAD adalah metode analisis yang memeriksa requirements dari sudut pandang kelas dan objek yang ditemui dalam ruang lingkup permasalahan yang mengarahkan arsitektur software yang didasarkan pada manipulasi objek-objek sistem atau subsistem. OOAD merupakan cara baru dalam memikirkan suatu masalah dengan menggunakan model yang dibuat menurut konsep sekitar dunia nyata. Dasar pembuatan adalah objek, yang merupakan kombinasi antara struktur data dan perilaku dalam satu entitas [7].

\section{Metode Penelitian}

Metode penelitian merupakan tahapan dalam penyusunan penelitian ini yang dimulai dari tahapan persiapan, pengumpulan data penelitian, analisa dan akuisisi pengetahuan, perancangan dan implementasi system, dan dokumentasi penelitian. Metodologi penelitian ini digunakan untuk memudahkan dalam menjelaskan proses penyusunan penelitian yang dibuat dalam bentuk flowchart.

\section{Persiapan}

Tahapan persiapan dilakukan untuk mempersiapkan segala sesuatu yang berhubungan dengan penelitian.

\section{Pengumpulan Data Penelitian}

Pengumpulan data dilakukan dengan dua cara, pertama dengan melakukan wawancara atau Tanya jawab dengan guru serta siswa yang berhubngan dengan penelitian dan yang kedua mencari bahan pendukung dalam menyelesaikan masalah melalui buku-buku dan internet yang berkaitan dengan penelitian.

\section{Analisa dan Akuisisi Pengetahuan}

Analisa dan akuisisi pengetahuan dilakukan untuk merumuskan masalah, mencari cara penyelesaian masalah, mencari algortima atuapun metode yang cocok dalam menyelesaikan masalah.

\section{Perancangan dan Implemensati Sistem}


Jurnal Sains, Teknologi dan Industri, Vol. 17, No. 2, Juni 2020, pp. 59 - 64

ISSN 2407-0939 print/ISSN 2721-2041 online

Perancangan sistem dikerjakan setelah semua tahap sebelumnya telah dilakukan, perancangan sistem membantu dalam mendefiniskan arsitektur sistem secara keseluruahn. Setelah perangan selesai dikerjakan, kemudian dilakukan pengimplementasian sistem kedalam bahasa pemorgaman yang telah di tentukan pada tahap sebelumnya.

\section{Pendefinisian Masalah \\ Analisa dan Hasil}

Dalam penelitian ini terdapat sebuah kasus yaitu pada pembelajaran IPA di SMP N 7 Pekanbaru hanya menggunakan buku sebagai media pembelajaran mengenai klasifikasi dan tata nama ilmiah pada tumbuhan. Dengan banyaknya jenis dan spesies tumbuhan, tentu ini akan menyulitkan pelajar maupun guru sebagai pengajar dalam proses belajar mengajar karna sumber belajar hanya didapat dari buku yang mana hanya sebagian saja nama latin tumbuhan yang terdapat dalam buku tersebut. Karena itu, dibutuhkan sebuah sistem yang dapat menampung seluruh nama ilmiah tumbuhan dan sebuah search engine untuk melakakukan pencarian nama tumbuhan yang sudah di tambahkan ke dalam sistem sebelumnya.

\section{Pemecahan Masalah}

Dalam pemecahan masalah ini akan dijelaskan bagaimana cara menyelesaikan masalah yang telah di uraikan diatas. Sebelum melakukan pembuatan sistem, perlu dilakukannya analisa dan perancangan agar sistem yang akan dibuat tergambarkan dengan jelas.

Sistem yang dirancang merupakan sistem berbasis website yang berfungsi sebagai media yang menghubungkan dengan tempat penyimpanan data (database) nama latin tumbuhan yang dikelolah oleh adminisitrator. Administrator berfungsi sebagai pengelolah sistem tersebut yang dapat menambahkan, mengedit, dan mengahapus nama latin tumbuhan pada database memalui sistem ini.

Pengguna (siswa dan guru) yang ingin melakukan pencarian nama latin tumbuhan pada sistem menggunakan suatu antar muka pengguna yang berbentuk search engine yang sudah kita kenal, seperti Google, Yahoo, Bing dan lain sebagainya. Pengguna harus memasukkan suatu kata kunci berdasarkan nama latin tumbuhan yang ingin dicari pada Search Engine, setelah perintah pencarian dieksekusi oleh pengguna, maka sistem akan mencari data sesuai dengan kata kunci tersebut pada database kemudian menampilkannya kepada pengguna sebagai hasil pencarian.

Untuk menggambarkan urutan kegiatan proses pada sistem ini, maka dibuatkan diagram alur kegiatan pada sistem yang dapat dilihat pada gambar berikut ini.
Gambar 1. Alur sistem pencarian nama latin tumbuhan

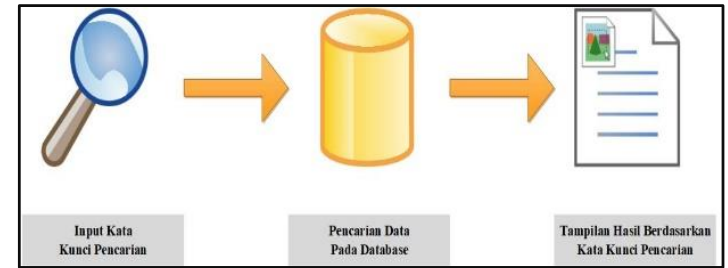

\section{Perancangan Sistem}

Perancangan sistem perlu dilakukan sebelum dilakukannya pembuatan sistem. Tujuan dari perancangan sistem adalah untuk menentukan, mengorganisir, dan membentuk komponen dari solusi sistem akhir sehingga memiliki blueprint untuk membangun sistem[10].

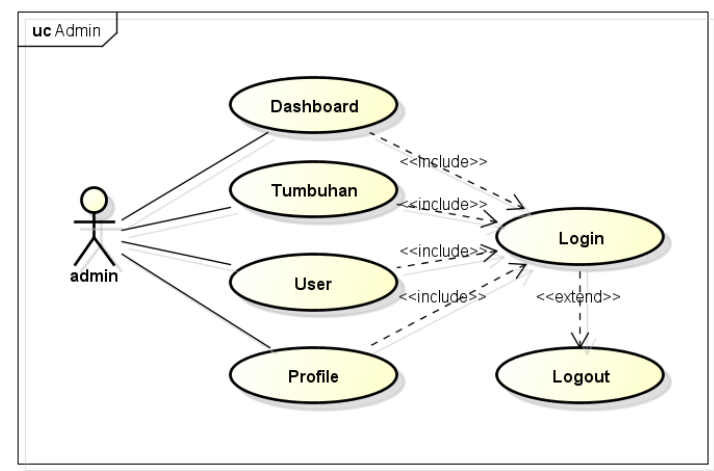

Gambar 2. Usecase diagram admin

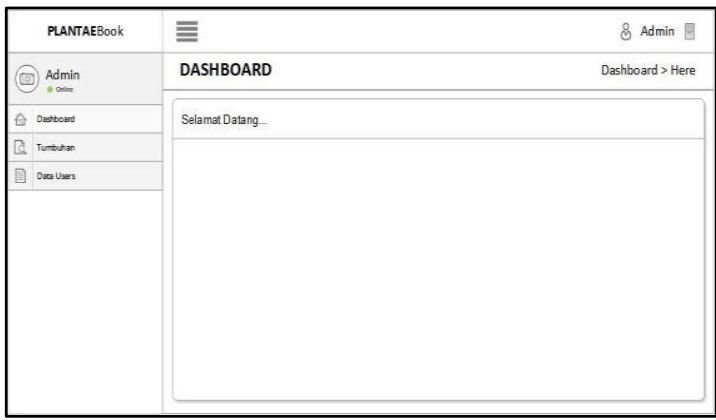

Gambar 3. Perancangan interface dashboard admin

D PLANTAEBook

PLANTAEbook

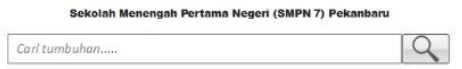

Gambar 3. Perancangan interface search engine

\section{Implementasi Sistem}

Terdapat dua pemahaman dasar tentang implementasi sistem, yaitu implementasi sistem yang merupakan tahapan coding (proses merangkai dan menguji kode-kode yang berisi algoritma untuk 
Jurnal Sains, Teknologi dan Industri, Vol. 17, No. 2, Juni 2020, pp. 59 - 64

ISSN 2407-0939 print/ISSN 2721-2041 online

membuat fitur yang sesuai dengan kebutuhan sistem dan user) menggunakan bahasa pemograman tertentu, dan implementasi sistem ke situasi nyata yang akan berurusan dengan pemilihan perangkat keras dan penyusunan perangkat lunak.

\section{Implementasi Antarmuka Sistem}
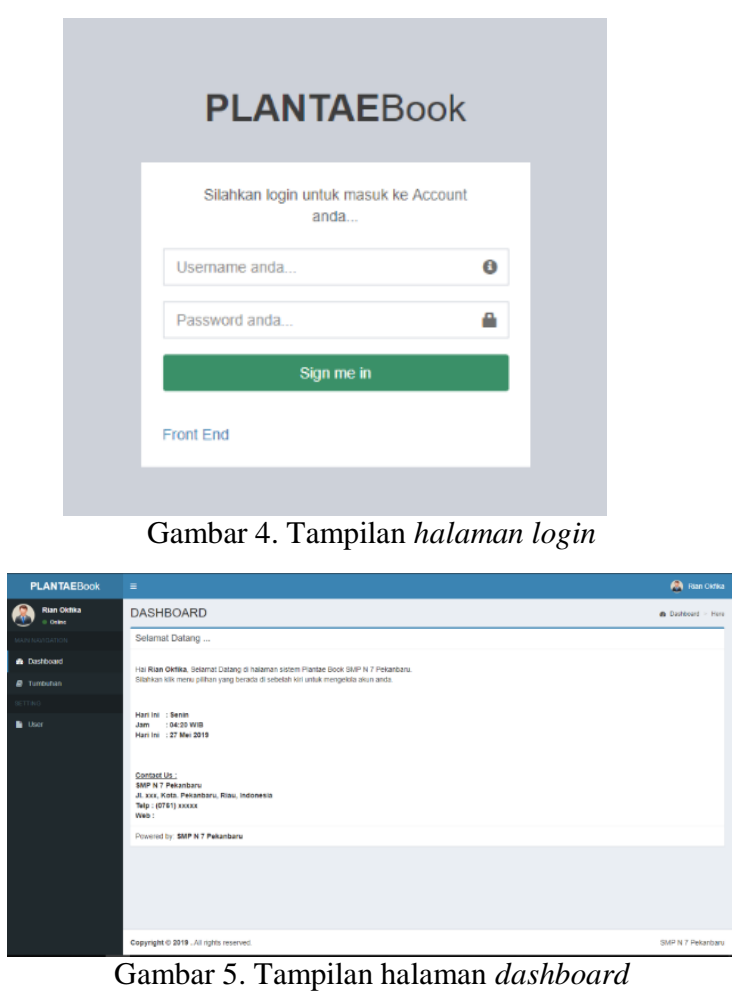

Gambar 6. Halaman Search Engine

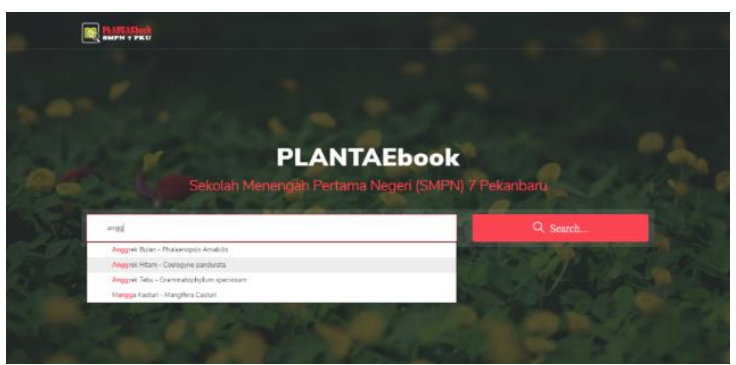

Gambar 7. Implementasi Algoritma Knuth Morris Pratt

\section{Pengujian Sistem}

Pengujian sistem yang digunakan adalah jenis pengujian blackbox. Jenis pengujian blackbox adalah dimana proses uji ditampilkan dalam bentuk tabel yang didalamnya menjelaskan tentang deskripsi pengujian, prosedur pengujian, data masukkan yang digunakan, kriteria evaluasi hasil, hasil yang didapat dari pengujian dan terakhir kesimpulan pengujian. Teknik yang digunakan untuk melakukan test cases pada sistem yang dibangun ini disebut functional analysist. Pengujian sistem pencarian nama latin tumbuhan menggunakan algoritma knuth morris pratt dapat dilihat pada tabel berikut.

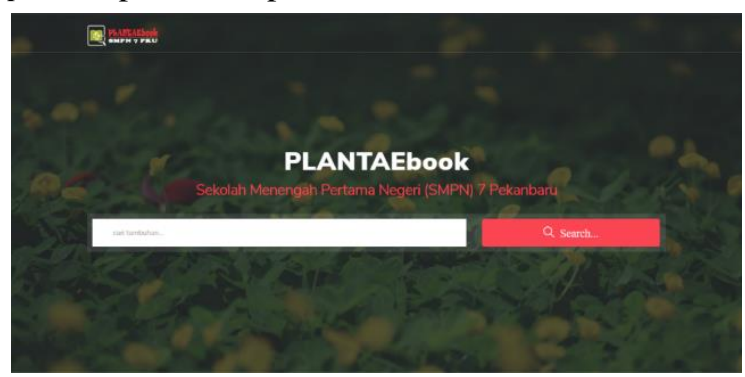


Jurnal Sains, Teknologi dan Industri, Vol. 17, No. 2, Juni 2020, pp. 59 - 64

ISSN 2407-0939 print/ISSN 2721-2041 online

Tabel 1. Identifikasi pengujian sistem administrator

\begin{tabular}{|c|c|c|c|c|c|}
\hline \multirow{2}{*}{ No } & \multirow{2}{*}{ Deskripsi pengujian } & \multirow{2}{*}{ Prosedur pengujian } & \multirow{2}{*}{ Data masukan } & \multicolumn{2}{|c|}{ Kriteria evaluasi hasil } \\
\hline & & & & Berhasil & Tidak berhasil \\
\hline 1 & Login & $\begin{array}{c}\text { Buka website } \\
\text { PLANTAEBook/admin, } \\
\text { menu login }\end{array}$ & $\begin{array}{l}\text { Input username dan } \\
\text { password }\end{array}$ & $\sqrt{ }$ & - \\
\hline 2 & Halaman dashboard & $\begin{array}{c}\text { Masuk halaman } \\
\text { dashboard setelah login }\end{array}$ & - & $\sqrt{ }$ & - \\
\hline \multirow{4}{*}{3} & \multirow{4}{*}{ Halaman tumbuhan } & Buka halaman tumbuhan & - & $\sqrt{ }$ & - \\
\hline & & Tambah tumbuhan & $\begin{array}{l}\text { Input nama tumbuhan, } \\
\text { nama latin, kingdom, } \\
\text { divisi, kelas, ordo, famili, } \\
\text { gambar tumbuhan, dan } \\
\text { keterangan tumbuhan }\end{array}$ & $\sqrt{ }$ & - \\
\hline & & Edit tumbuhan & $\begin{array}{l}\text { Update nama tumbuhan, } \\
\text { nama latin, kingdom, } \\
\text { divisi, kelas, ordo, famili, } \\
\text { dan keterangan tumbuhan }\end{array}$ & $\sqrt{ }$ & - \\
\hline & & Hapus Tumbuhan & - & $\sqrt{ }$ & - \\
\hline \multirow{4}{*}{4} & \multirow{4}{*}{ Halaman user } & Buka halaman user & - & $\sqrt{ }$ & \\
\hline & & Tambah user & $\begin{array}{l}\text { Input nama user, tempat } \\
\text { lahir, tanggal lahir, } \\
\text { alamat, nomor telphon, } \\
\text { username, dan level user. }\end{array}$ & $\sqrt{ }$ & - \\
\hline & & Edit user & $\begin{array}{l}\text { update nama user, tempat } \\
\text { lahir, tanggal lahir, } \\
\text { alamat, nomor telphon, } \\
\text { username, dan level user. }\end{array}$ & $\sqrt{ }$ & - \\
\hline & & Hapus $u$ ser & - & $\sqrt{ }$ & - \\
\hline \multirow[b]{2}{*}{5} & \multirow[b]{2}{*}{ Profile } & Buka halaman profile & - & $\sqrt{ }$ & - \\
\hline & & Update profile & $\begin{array}{c}\text { update nama, tempat } \\
\text { lahir, tanggal lahir, } \\
\text { alamat, nomor telphon, } \\
\text { username, dan password }\end{array}$ & $\sqrt{ }$ & - \\
\hline
\end{tabular}

\section{Kesimpulan}

Kesimpulan dari penelitian ini yaitu telah berhasil dibangun aplikasi pencarian nama latin tumbuhan menggunakan algoritma Knuth Morris Pratt berbasis web yang diberi nama PLANTAEBook. PLANTAEBook dibangun untuk menampilakan nama latin tumbuhan berdasarkan kata kunci (keyword) yang di-input-kan oleh pengguna sistem.

\section{Daftar Pustaka}

[1] APJII. (2017). Profil Pengguna Internet Indonesia 2016. Asosiasi Penyelenggara Jasa Internet Indonesia, Jakarta.

[2] Basee, S. (2000) Computer Algorithms: Introduction to Design and Analysis.

[3] Pressman, Roger S. (2012) Rekayasa Perangkat Lunak Pendekatan Praktisi Edisi 7. Yogyakarta: ANDI.

[4] Saragih A. S., (2016). Implementasi Algoritma Knuth-Morris-Pratt Pada Pencarian Kumpulan Rumus Matematika, Jurnal INFOTEK, 1(2).

[5] Suroso, A. dan Permatasari, A. (2003), Ensiklopedia Sains dan Kehidupan: Refernsi dan Petunjuk Lengkap untuk ilmu Biologi, Fisika, dan Kimia, CV Tarity Samudra Berlian, Jakarta.
[6] Susanto, A. E. (2015). Sejarah Bahasa Latin, www.scribd.com/doc/127313880/Sejarah-

Bahasa-Latin\#scribd on 10 Desember 2015.

[7] Syafir, Muhammad. (2017). Implementasi Algoritma String Matching Dalam Pencaria Surah Dan Ayat Dalam Al-Quran Berbasis Web., Indonesian Journal on Networking and Security, 6(2).

[8] Waruwu, F. T., \& Mandala, R. (2016). Perbandingan Algoritma Knuth Morris Pratt Dan Boyer Moore Dalam Pencocokan String Pada Aplikasi Kamus Bahasa Nias. J. Ilm. INFOTEK, l(1).

[9] Daeli, M. M. Y., \& Hondro, R. K. (2017). PERANCANGAN APLIKASI PENCARIAN KATA DENGAN KOMBINASI ALGORITMA KNUTH MORRIS PRATT DAN ALGORITMA BOYER MOORE. Informasi dan Teknologi Ilmiah (INTI), 12(2).

[10] Hamzah, M. L., Purwati, A. A., Rusilawati, E., \& Hamzah. (2019). Rapid Application Development In Design Of Library Information System In Higher Education. International Journal of Scientific \& Technology Research, 8(11), 153-156. 